\title{
Kolaborasi Teknik Picture and Picture dan Make A Match Bersetting Lesson Study Terhadap Hasil Belajar
}

\author{
Ni Md. Nia Widiya Paramita'1, I Kt. Dharsana², I Md. Tegeh ${ }^{3}$ \\ Prodi Pendidikan Guru Sekolah Dasar, Universitas Pendidikan Ganesha, Singaraja Indonesia \\ e-mail: niaparamita117@gmail.com 1 , profdarsana@yahoo.com ${ }^{2}$, imadetegehderana@yahoo.com ${ }^{3}$
}

\begin{abstract}
ABSTRAK
Penelitian dengan permasalahan rendahnya hasil belajar tematik maka, bertujuan untuk mengetahui efektivitas kooperatif teknik Picture and Picture dan teknik Make a Match dalam Setting Lesson Study terkait pembelajaran tematik kelas III SD. Penelitian ini merupakan jenis eksperimen semu melalui tata cara penelitian desain RCTs. Populasi yang digunakan yakni siswa kelas III A sejumlah 28 orang. Populasi untuk kelompok eksperimen kelas III A berjumlah 14 orang yang diberikan perlakuan menggunakan teknik picture and picture dan teknik make a match dan 14 orang kelas III A sebagai kelompok kontrol. Pemerolehan data tematik siswa dikumpulkan mempergunakan perangkat tes berbentuk pilihan ganda sebanyak 30 soal. Data yang telah terkumul kemudian dianalisis mempergunakan statistik deskriptif dan Independen Sample $t$-test. Berdasarkkan penelitian, rata-rata belajar pendekatan tematik siswa kelompok eksperimen $\bar{X}=23$. Serta setelah dilakukan uji hipotesis menggunakan SPSS 25.00 for Windows pada tabel keputusan diperoleh nilai Sig. (2-tailed) $=0,043$ artinya nilai signifikansi (2-tailed) $<0,05$ maka $\mathrm{H}_{0}$ ditolak dan $\mathrm{H}_{1}$ diterima. Hasil penelitian menunjukkan terdapat pengaruh signifikan pada eksperimen setelah diajarkan melalui teknik picture and picture dan teknik make a match dalam setting lesson study dengan kelompok kontrol yang dibelajaran guru seperti biasa pada hasil belajar siswa. Dengan demikian disimpulan bahwa teori konstruktivis model pembelajaran dengan kolaborasi teknik picture and picture dan make a match bersetting lesson study efektif terhadap hasil belajar tematik siswa kelas III A Sekolah Dasar dapat ditingkatkan.
\end{abstract}

Kata kunci: Hasil belajar, Setting lesson study

\begin{abstract}
Research with the problem of low thematic learning outcomes then, aims to determine the effectiveness of cooperative picture and picture techniques and the Make a Match technique in Lesson Study settings related to thematic learning of third grade elementary schools. This research is a type of quasi-experimental research using RCTs design procedures. The population used is the class III A number of 28 people. The population for the class III A experimental group was 14 people who were treated using picture and picture techniques and make a match techniques and 14 class III A people as the control group. Obtaining students' thematic data was collected using 30 multiple choice test items. The collected data is then analyzed using descriptive statistics and Independent Sample t-test. Based on the research, the average of thematic learning approaches in the experimental group students $=23$. And after the hypothesis testing using SPSS 25.00 for Windows in the decision table the value of Sig. (2-tailed) $=0.043$ means that the significance value (2-tailed) $<0.05$ then $\mathrm{H} 0$ is rejected and $\mathrm{H} 1$ is accepted. The results showed there was a significant influence on experiments after being taught through picture and picture techniques and make a match techniques in the setting of lesson study with the control group that the teacher learned as usual on student learning outcomes. Thus it can be concluded that the constructivist theory of learning models with the collaboration of picture and picture techniques and make a match setting lesson study is effective on the thematic learning outcomes of third grade A elementary school students.
\end{abstract}

Keywords: Learning outcomes, Setting lesson study

*Corresponding author.

Received 20 April 2020, Accepted 20 Juni 2020; Available online 5 Juli 2020

(C) 2020 MI All Rights Reserved

Jurnal Mimbar IImu | 240 


\section{Pendahuluan}

Pendidikan sekolah dasar kini dijadikan sebagai jenjang pendidikan formal yang memiliki peran penting bagi keberlangsungan dalam proses pendidikan selanjutnya. (Sakdiah, 2019) SD merupakan salah satu sumber pendidikan dasar bagi anak untuk memperoleh ilmu setelah mereka dididik oleh orang tuanya. Pada lingkungan SD mereka akan mendapat bimbingan berupa pendidikan formal dari seorang guru, dan ilmu pengetahuan yang baru. Pembelajaran di SD yang berlangsung selama 6 tahun akan membentuk karakter siswa untuk kedepannya. Siswa mendapat ilmu pengetahuan dan mendapat nilai-nilai yang nantinya akan berguna dalam kehidupan. Setiap siswa dalam proses belajar di sekolah akan berbeda karena mereka memiliki kemampuan yang berbeda-beda dalam menerima pembelajaran yang diajarkan oleh guru.

Pembelajaran akan bermakna apabila dalam proses belajar terdapat interaksi antara guru dan siswa. Pembelajaran merupakan terjadinya interaksi antara komponen-komponen yang terdapat dalam sistem pembelajaran (Daryanto \& Rahardjo, 2012:30). Pembelajaran digunakan untuk menunjukkan terjadinya kegiatan antara guru dan siswa, atau memungkinkan terjadinya proses belajar pada siswa itu sendiri. Ciri dari pembelajaran terdapat komponen yang saling berkaitan satu sama lain seperti tujuan, materi, kegiatan dan evaluasi pembelajaran. Siswa akan memperoleh pengalaman belajar dari beberapa mata pelajaran yang wajib didapat di sekolah dasar. Berdasarkan Peraturan Menteri Pendidikan Nasional Republik Indonesia Nomor 22 Tahun 2006 untuk kurikulum SD/MI memuat 8 mata pelajaran, muatan lokal, dan pengembangan diri. Pembelajaran pada kelas I sampai kelas III dilaksanakan melalui pendekatan tematik, sedangkan kelas IV sampai kelas VI dilaksanakan melalui mata pelajaran. Pendekatan tematik menjadi salah satu pembelajaran yang wajib untuk jenjang sekolah dasar. Setelah dilakukan observasi dilihat hasil belajar dari pendekatan tematik siswa di kelas III A masih kurang, maka perlu dilakukan bimbingan dan diberikan perhatian terhadap siswa yang masih kurang namun siswa yang nilainya bagus tetap diberikan perhatian.

Rendahnya kualitas hasil belajar khususnya pendekatan tematik terdapat faktor internal atau dari dalam yang kurang mendukung proses pembelajaran siswa, seperti kurangnya motivasi belajar yang dimiliki oleh siswa, dan faktor eksternal atau dari luar yang kurang dalam penerapan teknik pembelajaran yang kreatif dan inofatif. Kreatifitas yang dimiliki oleh guru akan mempengaruhi proses belajar siswa, apakah siswa akan lebih banyak diam, merasa bosan dan jenuh, dan kurang aktif dalam proses pembelajaran atau sebaliknya, jika guru menggunakan bantuan teknik pembelajaran siswa akan tidak merasa bosan (Sukmawati, Dantes, \& Dibia, 2019).

Bersumber pada hasil wawancara, observasi serta pencatatan dokumen dilakukan pada tanggal 04 November 2019. Wawancara, observasi dan pencatatan dokumen dilakukan untuk mengetahui minat siswa terkait pembelajaran di kelas mengenai pembelajaran kurikulum 2013 mengenai penekanan pengembangan kemampuan (Afiyahni, Huda, \& Listyarini, 2019). Wawancara yang dilakukan terhadap 28 siswa kelas III A, terdapat 17 siswa menyukai PPKn, 13 siswa tidak menyukai PPKn, 10 siswa menyukai matematika, 7 siswa tidak menyukai matematika dan 3 siswa menyukai mata pelajaran Bahasa Indonesia, serta10 siswa menyatakan kurang menyukai pelajaran Bahasa Indonesia. Salah satu wawancara yang dilakukan terhadap siswa kelas III A menyatakan kurang menyukai salah satu mata pelajaran karena proses pembelajaran di kelas dirasanya membosankan apalagi pada jam terakhir yang membuat dirinya merasa mengantuk. Sedangkan tiga siswa mengaku menyukai salah satu mata pelajaran karena menurut mereka pelajaran tersebut terdapat cerita-cerita yang menarik yang membuat mereka menjadi suka membaca dan tampak pelajaran yang berkaitan dengan kehidupan sehari-hari(Arnista, Saputra, \& Azizah, 2019).

Dari hasil observasi di kelas siswa terlihat kurang bersemangat mengikuti proses pembelajaran dan memilih menggoda teman sebangkunya untuk diajak bermain, apalagi pada jam-jam terakhir beberapa siswa terlihat mengganggu teman sebangkunya, karena minat siswa menerima pembelajar sudah berkurang, serta siswa kurang termotivasi. Hasil yang didapat saat observasi pada saat guru melakukan proses pembelajaran di kelas yaitu: (1) Pembelajaran yang dilaksanakan guru di kelas masih terlihat memanfaatkan pembelajaran berpusat pada guru (teacher centered), yakni menggunakan teknik ceramah yang berlebihan. (2) Penggunaan media pembelajaran, media yang dipergunakan kurang bervariasi maka siswa terasa bosan dan kurang bersemangat dalam mengikuti proses pembelajaran. (3) Guru kurang mengaitkan materi 
pembelajaran dengan kehidupan sehari-hari siswa. Hal ini tentu berpengaruh pada hasil belajar siswa di kelas.

Wawancara yang dilakukan dengan wali kelas III A SD Negeri 1 Baktiseraga, diperoleh siswa sebagian besar menunjukkan perilaku belajar sangat tinggi, namun hasil PTS yang didapat sangat rendah, dan dikukung pula melalui pencatatan dokumen yang diperoleh nilai rata-rata PTS siswa kelas III A yaitu: pelajaran PPKn nilai rata-rata PTS siswa 84,75 pelajaran Matematika nilai rata-rata PTS siswa 70, pelajaran Bahasa Indonesia nilai rata-rata PTS siswa 69,79 dan mata pelajaran Seni Budaya dan Prakarya nilai rata-rata siswa 53. Dirujuk berdasarkan hasil wawancara diduga penyebab rendahnya hasil belajar siswa yakni dari proses pembelajaran yang dilaksanakan masih banyak berpusat pada guru dan kurangnya memanfaatkan strategi, serta teknik pembelajaran yang bervariasi yang dilihat melalui hasil observasi yang dilakukan. Melalui teknik pembelajaran yang efektif akan menimbulkan rasa belajar yang timbul pada siswa. Agar siswa dapat menyerap mata pelajaran secara optimal, maka guru harus menetapkan teknik belajar yang tepat dan tentunya didukung adanya media pembelajaran yang memadai dalam mengajar (Anggraeni, dkk., 2019). Salah satunya melalui teknik pembelajaran yang dapat mengaktifkan siswa yakni teknik picture and picture dan make a match.

Untuk mengetahui teknik yang diterapkan efektif atau tidak makan dapat dilakukan melalui evaluasi (Sri, 2018). Evaluasi yang diperoleh akan dipergunakan untuk perbaikan cara mengajar maupun proses belajar siswa, atau biasanya hasil evaluasi yang dipergunakan sebagai kenaikan kelas atau dijadikan sebagai penentu lulus atau tidak lulusnya siswa dari suatu lembaga pendidikan tertentu. (Dharsana, 2018) Kegiatan akhir akan memberitahu intelegensi siswa yang dimiliki siswa serta dapat memberikan penilaian mengenai cerdes atau tidak siswa tersebut. Perlu adanya alternatif untuk mengatasi masalah terkait pembahasan di atas, seperti perlu diterapkannya berbagai jenis pendekatan, strategi, dan model atau teknik dalam proses pembelajaran.

Disamping itu perlu juga untuk menerapkan teori belajar dalam meningkatkan hasil belajar siswa. (Dharsana, dkk., 2019) kondisi atau keadaan belajar dilingkungan dapat diubah melalui penerapan beragam teknik, salah satu teori belajar yang cocok dipergunakan ialah teori belajar konstruktivis. konstruktivis menekankan siswa terhadap peran utama dalam proses belajar yang memperoleh kesempatan untuk menyusun pengetahuannya sendiri sesuai dengan kemampuan dan lingkungannya sendiri (Margunayasa, Arini, \& Japa, 2014:7). Terjadinya teknik pembelajaran yang efisien akan menimbulkan pembelajaran bermakna terhadap siswa melalui rasa senang dan sifat emati yang dimiliki siswa akan menuntun sifat secara natural (Dharsana, 2014).

Pembelajaran efektif tentunya dapat melalui penerapan pembelajaran yang sesuai terhadap bantuan media pembelajaran (Cahyani, dkk., 2015). Terjadinya efektif terhadap pembelajaran akan menimbulkan pembelajaran berarti terhadap siswa serta terjadi indikator seperti dapat menyelesaikan suatu hal dengan baik serta berhasil mengerjakan tugas yang dibarengi dengan usaha, dan mampu menuntaskan hal penting serta lebih baik dari siapapun (Azhar, dkk., 2019:59). Teknik yang terjadi dalam ruang kelas bersifat implementatif, dapat diartikan teknik sebagi cara yang dilakukan guru dalam mengimplementasikan suatu metode secara spesifik (Mukrimah, 2014). Agar siswa dapat menyerap mata pelajaran secara optimal, maka guru harus menetapkan teknik belajar yang tepat dan tentunya didukung adanya media pembelajaran yang memadai dalam mengajar. Teori belajar konstruktivis, salah satu model pembelajaran yang digunakan mengatasi permasalahan kurang aktif dan hasil belajar yang rendah adalah melalui pembelajaran model kooperatif teknik picture and picture dan teknik make a match. Dua teknik ini dapat membantu meningkatkan aktivitas dalam hasil belajar melalui kelompok kecil melalui bantuan gambar, kartu berisikan soal dan jawaban. Rangkaian pembelajaran secara kelompok akan mengantarkan tujuan pembelajaran tercapai, kelompok diartikan dua orang individu atau lebih yang berinteraksi melalui tatap muka serta tiap individu menyadari dirinya merupakan bagian dari kelompok dan menimbulkan rasa saling ketergatungan secara positif yang digunakan untuk mencapai tujuan (Putra, dkk., 2015). Untuk meningkatkan kualitas pembelajaran guru dapat melakukan kegiatan yang dapat mendorong sebuah komunikasi untuk melakukan perbaikan baik dari individu maupun manajerial yaknik melalui setting lesson study yang merupakan pembinaan model profesi terhadap pendidik melalui pengkajian pembelajaran secara kolaboratif dan berkelanjutan (Tristiantari dan Sumantri, 2016:206). Kunci pelaksanaan setting lesson study 
adalah aktivitas siswa di kelas dengan anggapan siswa terikat dengan aktivitas guru selama proses mengajar (Laila, dkk., 2019:88). Dengan penerapan teknik picture and picture dan teknik make a match dalam setting lesson study, diharapkan dapat meningkatkan hasil belajar siswa kelas III A SD Negeri 1 Baktiseraga.

\section{Metode}

Dalam penelitian ini melakukan beberapa langkah pertama terdapat langakah plen yang dilakukan dengan mempergunakan metode penelitian yang mengumpulkan data hasil belajar siswa adalah dengan menggunakan tes objektif (tes pilihan ganda) melalui pre-test dan pos-test. Tes objektif yang digunakan dalam penelitian ini berupa pilihan ganda yang terdiri dari 4 pilihan jawaban (A; B; C dan D) yang salah satunya terdapat jawaban yang benar. Jumlah soal pilihan ganda ada 30 soal yang dapat mengungkapkan penguasaan siswa terhadap pelajaran tiap item soal. Diberikan skor 1 (satu) bila jawaban tersebut benar, diberikan skor 0 (nol) apabila jawaban salah. Skor minimal verifikasi hasil belajar adalah 0 dan skor maksimal adalah 30 , jadi nilai siswa berkisar dari 0 sampai 100, dalam pengolahan skor hasil belajar siswa dari skor mentah menjadi skor standar menggunakan PAP (Penilaian Acuan Patokan). Tes objektif pilihan ganda disusun dengan kisi-kisi yang akan memberikan informasi mengenai tiap butir soal yang akan muncul dan hasil tes tersebut akan memberikan informasi berupa data dalam bentuk skor atau interval. Hasil belajar tematik yang dinilai dari segi perkembangan pengetahuan siswa. Tes dibuat dengan mempergunakan acuan Taxonomi Bloom Revisi, tes hasil belajar disesuaikan dengan SK dan KD pembelajaran.

Pertama yang dilakukan adalah merancang pembelajaran untuk pelaksanaan open clas yang efektif, dengan menggunakan teknik picture and picture dan teknik make a match, dalam melaksanakan open class ada beberapa hal yang harus dipersiapkan dalam teknik yang digunakan. Teknik picture and picture hal pertama harus menyediakan gambar yang berkaitan dengan pembelajaran yang akan diberikan, nanti siswa akan mengurutkan gambar yang diberikan secara berkelompok. Hal pertama yang harus disiapkan dalam teknik make a match adalah membuat potongan kertas sejumlah siswa, bagian kertas tersebut dituliskan jawaban atau soal sesuai materi yang akan diajarkan dan meminta siswa untuk menemukan pasangan mereka melalui potongan kertas yang mereka bawa. Apabila media yang diguunakan sudah tersedia guru dapat menggunakannya dalam mengajar agar siswa menjadi aktif.

Pengambilan populai menggunakan acak sederhana (simple random sampling), dalam Budiarto, (2004:38-39) "pengambilan populasi acak sederhana, merupakan pengambilan dengan menyesuaikan tiap individu sehingga mempunyai kesempatan yang sama dijadikan sebagai populasi". Populasi dalam penelitian ini terdiri dari 28 siswa yang dimisalkan dalam bentuk abjad, dimulai dari $A, B, C, D, E, F, G, H, I, J, K, L, M, N, \ldots$ hingga berjumlah 28 , dalam menentukan jumlah populasi yang mana antara kontrol dan eksperimen maka peneliti mempergunakan teknik randomized (acak). Pada kelompok kontrol didapat siswa dengan kode $\mathrm{C}, \mathrm{E}, \mathrm{F}, \mathrm{M}, \ldots$ hingga berjumlah 14 begitupun untuk kelompok eksperimen diacak dan didapat siswa dengan kode $A, B, D, G, \ldots$ hingga berjumlah 14 siswa yang dikelompokkan dan diajarkan menggunakan teknik picture and picture serta teknik make a match. Adapun keuntungan terkait pengambilan populasi secara acak sederhana seperti ketepan yang tinggi dan tiap sampel mempunyai probabilitas sama untuk diambil sebagai populasi dan sampling error dapat ditentukan secara kuantitatif.

Setelah mengetahui pengetahuan awal siswa baru diberikan perlakuan mempergunakan teknik picture and picture dan make a match yakni pada tahap do. Do (pelaksanaan), melaksanakan proses pengajaran dengan menggunakan teknik picture and picture dan teknik make a match dengan dua kelompok dalam satu kelas secara bersamaan. Untuk mengetahui siswa senang atau tidak siswa diberikan jurnal refleksi untuk menilai berlangsungnya pembelajaran, dan siswa diberikan pos-test untuk tahu pemahaman siswa setelah diajarkakn dengan bantuan penggunaan tekni picture an picture dan teknik make a match.

Penelitian ini menggunakan metode eksperimen jenis semu (Quasi Exsperimental Design), karena kelompok eksperimennya mempergunakan kelas dan kelas terseebut terdapat kelompok kontrol namun tidak berfungsi sepenuhnya untuk mengontrol variabel luar eksperimen. Dengan rancangan penelitian desain penelitian Randomized Control Trials (RCTs), desain yang paling kuat untuk mengevaluasi yang digunakan untuk menunjukkan bahwa interval yang digunakan benar- 
benar layak. mengenai randomized terkait RCTs berarti subjek penelitian memiliki peluang sama untuk ditempatkan melalui acak baik kelompok tindakan kelompok eksperimen serta kelompok kontrol. Kata control trials bermakna terdapat tindakan lain dijadikan kontrol tindakan eksperimen.

Rancangan penelitian yang dilakukan hanya menggunakan kelas III A terbagi menjadi dua kelompok. Satu kelompok eksperimen dan satunya kelompok kontrol, melalui desain randomized Control Trials (RCT). Siswa terlebih dahulu diberikan pre-test untuk mengetahui pengetahuan awal siswa terkait materi yang akan diajarkan. Soal yang diberi siswa kelas III terkait mengenai tematik tema 6. Setelah mengetahui pemahaman awal siswa, kemudia kelompok eksperimen diberikan pembelajaran dengan bantuan teknik picture and picture dan teknik make a match, dan kelompok kontrol diberikan perlakuan seperti biasa oleh guru yang mengajar. Setelah kedua kelompok diberikan perlakuan terkait pelajaran tema 6 , kedua kelompok diberikan post-tes.

Kemudian dilakukan pengolahan data pre-tst dan post-tes melalui rata-rata (mean), data tengah (median), data yang banyak muncul (modus), dan standar deviasi. Analisis data juga menggunakan statistik inferensial berupa uji prasyarat dan uji-t untuk mengetahui kebenaran pada kelompok eksperimen dan kelompok kontrol yang diberikan perlakuan berbeda.

\section{Hasil dan Pembahasan}

Data dalam penelitian ini adalah skor hasil belajar tematik siswa kelas III A SD Negeri 1 Baktiseraga. Pengukuran terkait hasil belajar tematik siswa dilakukan setelah kelompok eksperimen dibelajarkan dengan teknik picture and picture dan teknik make a match dalam setting lesson study dan kelompok kontrol dibelajarkan oleh guru seperti biasa. Analisis data dilakukan pada masing-masing kelompok yaitu kelompok eksperimen dan kelompok kontrol. Adapun hasil analisis data statistik deskriptif disajikan pada Gambar 1.

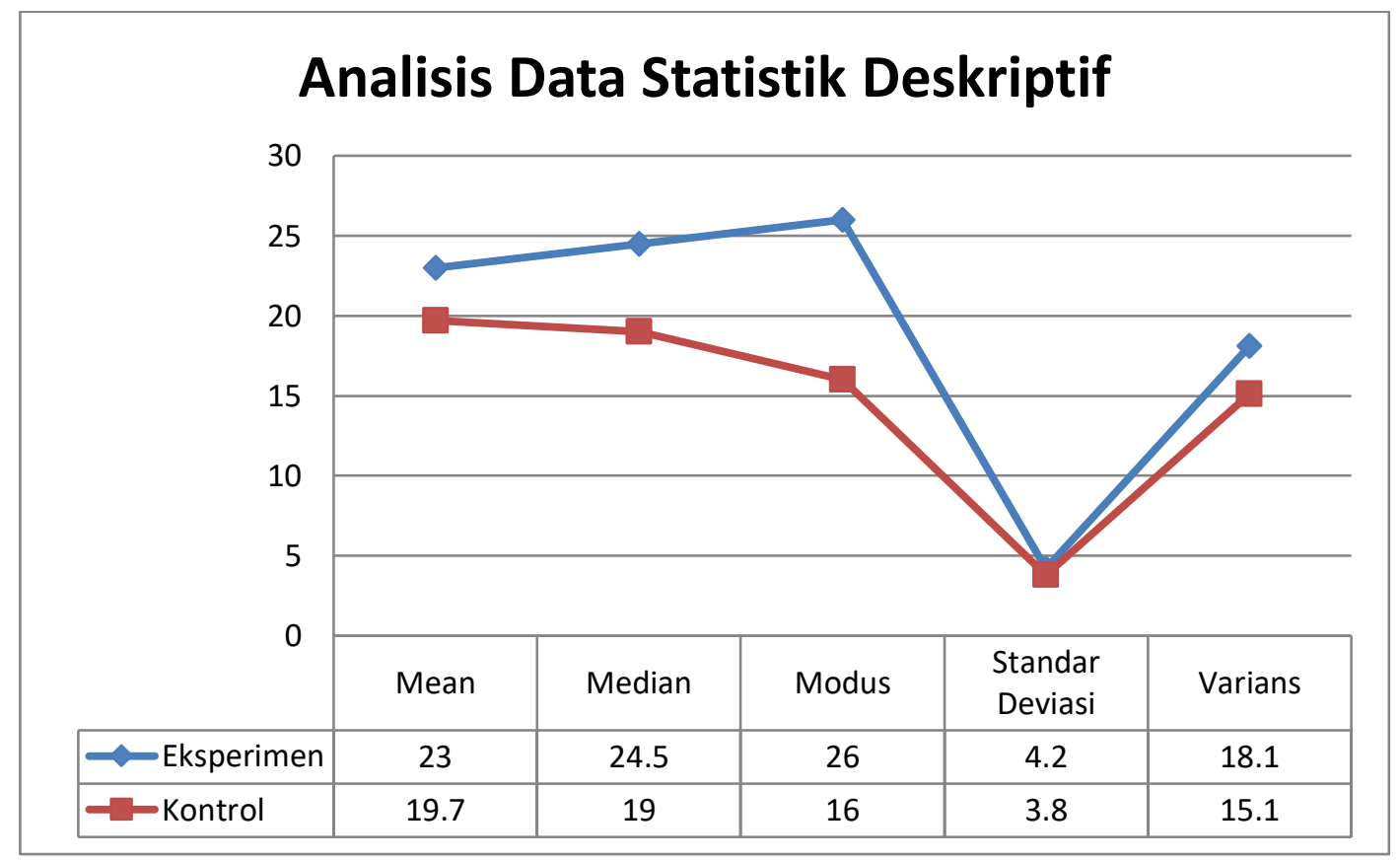

Gambar 1. Grafik Analisis Data dengan Statistik Deskriptif

Bersumber pada Gambar 1 di atas, diketahui kelompok eksperimen memiliki Mo>Md>M ( modus $=26$, median $=24,5$, dan mean $=23$ ), diartikan kualitas variabel dari hasil belajar tematik terkait kelompok eksperimen melalui skor rata-rata hasil belajar tematik siswa dikonversikan dengan menggunakan kriteria rata-rata ideal $\left(M_{1}\right)$ serta mempergunakan standar deviasi ideal $\left(\mathrm{SD}_{1}\right)$ maka diperoleh hasil pada rata-rata belajar tematik pada eksperimen dengan skor sebesar $\mathrm{M}=23$ dengan kriteria sangat tinggi. Pemahaman pada data grafik poligon eksperimen yang berupa grafik juling yang mengarah negative memiliki arti cenderung tinggi. 
Sedangkan kelompok kontrol memiliki $\mathrm{Mo}<\mathrm{Md}<\mathrm{M}$ (modus $=16$, media $=19$, dan mean $=$ $19,7)$ berarti lebih besar mean dari median dan median besar dari modus. Mengetahui kualitas variabel hasil belajar tematik kelompok pada kontrol rata-rata hasil belajar tematik siswa dikonversikan mempergunakan kriteria rata-rata ideal $\left(\mathrm{M}_{1}\right)$ serta standar deviasi ideal $\left(\mathrm{SD}_{1}\right)$, maka diperoleh konversi berupa hasil pada rata-rata hasil belajar tematik kelomok skor sebesar $M=19,7$ dengan kategori tinggi. Pemahaman pada grafik poligon kelompok kontrol yang berupa grafik yang arah julingnya mengarah ke positif, maka diartikan skor sebagian besar cenderung rendah.

Sebelum melakukan uji hipotesis hal pertama perlu melakukan uji prasyarat meliputi normalitas dan homogenitas. Uji prasyarat, dilakukan terkait pemerolehan data berupa skor hasil belajar tematik. Uji nomalitas dilakukan untuk membuktikan bahwa kedua kelompok tersebut berdistribusi normal, sedangkan uji homogenitas dilakukan untuk mendapatkan kedua kelas memiliki penguasaan relatif homogen atau sama.

Tabel 1. Uji Normalitas dengan SPSS 25.00

\begin{tabular}{|c|c|c|c|c|c|}
\hline \multicolumn{6}{|c|}{ Tests of Normality } \\
\hline \multirow[b]{2}{*}{ Skor } & \multirow[b]{2}{*}{ Postes } & \multicolumn{4}{|c|}{ Shapiro-Wilk } \\
\hline & & Statistic & $\mathrm{n}$ & Sig. & \\
\hline & Picture and Picture & .980 & 7 & & .958 \\
\hline & Make a Match & .929 & 7 & & .542 \\
\hline & Kontrol & .947 & 14 & & .516 \\
\hline
\end{tabular}

Hasil perhitungan uji normalitas pada Gambar 2 dengan bantuan SPSS 25.00 for windows terhadap kelompok eksperimen melalui pembelajaran dengan teknik picture and picture dan teknik make a match dalam setting lesson study dilihat dalam tabel Shapiro-Wilk. Nilai pada tabel Shapiro-Wilk didapat > 0,05 maka pemerolehan skor hasil post-test pada kelompok eksperimen dinyatakan berdistribusi normal.

Tabel 2. Uji homogenitas varians dengan bantuan SPSS 25.00

Levene

$\begin{array}{llll}\text { Statistic df1 } & \text { df2 }\end{array}$

\begin{tabular}{lllll}
\hline Post-test & .335 & 1 & 26 & .568
\end{tabular}

Tahap berikutnya dilakukan uji prasyarat uji homogenitas varians sepeti Gambar 3. Hasil uji homogen varians dilakukan dengan bantuan SPSS 25.00 for Windows mempergunakan Levene's Test pada hasil belajar pendekatan tematik dengan nilai signifikan $>0,05$ maka distribusi data homogen, namun apabila nilai signifikan $<0,05$ maka distribusi data tidak homogen. Hasil uji homogenitas varians data yang telah dianalisis diperoleh kelompok eksperimen dan kelompok kontrol terkait hasil belajar bernilai signifikan 0,568 , sehingga data berdistribusi homogen karena nila signifikan 0,568 $>0,05$.

Setelah uji normalitas dan homogenitas, selanjutnya dilakukan uji hipotesis dengan menggunakan uji-t sampel independent (tidak berkolerasi). Uji independen sampel t-tes 
menggunakan SPSS 25.00 for Windows syarat keputusan dengan melihat 2-tailed, memiliki arti signifikansi (2-tailed) $<0,05$ apabila menunjukkan perbedaan yang signifikan antara Kelompok eksperimen dengan kelompok kontrol. Ini menunjukkan terdapat pengaruh yang bermakna terkait perbedaan perlakuan yang diberikan terhadap kelompok eksperimen.

Tabel 3. Uji hipotesis

\section{Independent Samples Test}

t-test for Equality of Means

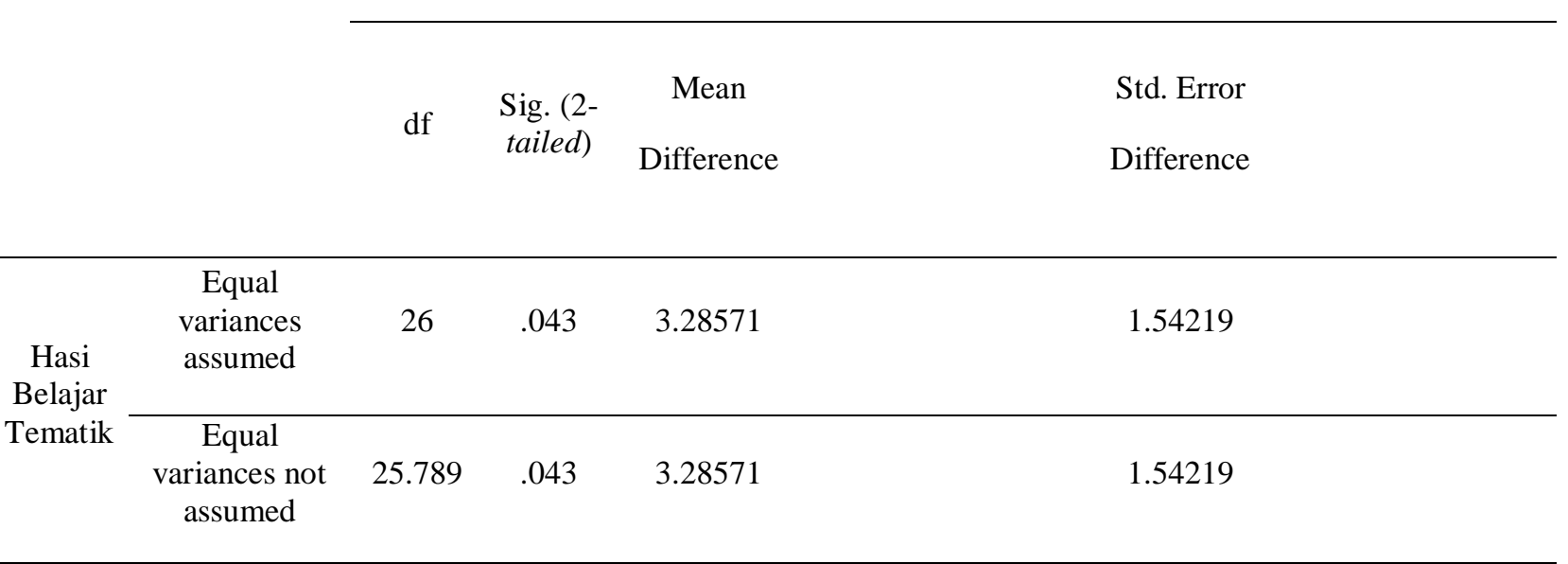

Dari Tabel 3, uji hipotesisi mengpergunakan analisis linear 2 arah maka yang diperhatikan adalah nilai pada sig 2-tailed. Hasil yang diperoleh dari uji-t 0,043 artinya nilai 2-tailed $=0,043$ $<0,05$ maka $\mathrm{H}_{0}$ ditolak dan $\mathrm{H}_{1}$ diterima yang artinya ada pengaruh yang signifikan dari pemberian treatment, maka diartikan sebagai berikut. Tampak pengaruh terhadap kelompok eksperimen secara signifikan yang diberikan perlakukan melalui teknik picture and picture dan teknik make a match melalui setting lesson study dengan kelompok kontrol yang dibelajarkan guru seperti biasa pada hasil belajar siswa kelas III A di SD Negeri 1 Baktiseraga. Perbedaan perhitungan hasil terkait rata-rata belajar tematik kelompok eksperimen sebesar 23, rata-rata kelompok eksperimen memiliki skor lebih besar ketimbang hasil belajar rata-rata kelompok kontrol adalah 19,7. Maka dari temuan hasil diperoleh bahwa teknik picture and picture serta teknik make a match dalam setting lesson study dapat mempengaruhi hasil belajar tematik terhadap siswa kelas III A SD. Negeri 1 Baktiseraga.

Berdasarkan hasil penelitian yang diperoleh perbedaan hasil belajar pendekatan tematik antara siswa pada kelompok eksperimen dan kelompok kontrol disebabkan adanya perbedaan pemberian perlakuan dalam proses pembelajaran. Perbedaan perlakuan dalam proses pembelajaran dapat terjadi dikarenakan beberapa hal. Pertama, proses pembelajaran yang dibelajarkan dengan teknik picture and picture dan teknik make a match yaitu: (1) penggunaan teknik ini dapat meningkatkan hasil belajar siswa, (2) siwa dapat berperan aktif mengikuti pembelajaran dari awal sampai akhir, (3) penggunaan teknik pembelajaran ini dapat memberikan pemahaman pada siswa untuk menggali pemahamannya melalui pertanyaan-pertanyaan yang disampaikan, (4) siswa dapat mengaitkan pengalaman yang telah didapat dengan pembelajaran yang siswa terima.

Model pembelajaran kooperatif teknik picture and picture dan teknik make a match dapat memberikan pengalaman baru terhadap siswa untuk menggali pengetahuan, sehingga mereka dapat meningkatkan pemahaman. Teknik pembelajaran ini tidak berpusat pada guru melainkan pada siswa sehingga siswa aktif menggali pengetahuannya. Teknik picture and picture merupakan suatu teknik yang menjadikan media gambar sebagai faktor utamanya, (Andriani, Sulasmoni, dkk., 2019) Teknik tipe picture and picture termasuk teknik pengajaran yang memanfaatkan media untuk menjelaskan materi, serta dapat dijadikan sebagai pendukung fasilitas siswa untuk menjelaskan 
materi sehingga siswa bersemangat dalam belajar. Picture and Picture dapat dijadikan solusi untuk mengatasi masalah yang dihadapi siswa, karena teknik pembelajaran ini mengandalkan gambar sebagai media dalam proses pembelajaran (Sukmawati, dkk., 2019:200). Penerapan teknik make a match dapat dijadikan alternatif untuk meningkatkan pemahaman siswa dengan karakteristik siswa yang masih senang bermain, dengan menggunakan sistem pengelompokan secara tim kecil (Arnista, dkk., 2019), dan dengan bantuan kartu jawaban dan soal yang nantinya siswa akan mencari pasangan kartu yang dibawanya dan pasagan kartu tersebut menjadi pasangan kelompok. Teknik make a match membantu siswa untuk bekerjasama dalam kelompok agar tanggung jawab dapat tercapai dan semua siswa dapat aktif dalam proses pembelajaran (Murtinugraha \& Arthur, 2014). Peran guru dalam pembelajaran hanya sebagai fasilitator dan moderator yang memberikan tanggung jawab kepada siswa untuk memperoleh sendiri pengtahuannya yang diperlukan melalui interaksi dengan anggota kelompoknya. Kedua karena penerapan teknik picture and picture dan teknik make a match yang diterapkan melalui setting lesson study.

Pengaruh hasil belajar yang dibelajarkan menggunakan teknik picture and picture serta make a match dalam setting leson study disebabkan oleh beberapa faktor yaitu sebagai berikut. Pertama, pelaksanaan pembelajaran menggunakan teknik picture and picture, make a match dalam setting lesson study menyebabkan siswa aktif dalam mengikuti pembelajaran dan bertanggung jawab didalam kelompok. Dalam setting lesson study pada tahap plan bersama wali kelas III A menyusun kisi-kisi, RPP, instrumen soal yang sudah diuji terlebih dahulu oleh pakar yang membidangi mata pelajaran tersebut. Perencanaan terdiri atas analisis kebutuhan dan permasalahan pembelajaran. Contohnya: kompetensi dasar, cara pembelajaran siswa, menyiasati kekurangan fasilitas belajar, dan pemecahan masalah secara kolaboratif. Sehingga pada tahap ini penggunaan teknik dapat mengajak siswa untuk terlibat langsung dalam pembelajaran melalui saling bekerjasama dan mengeluarkan pendapat, siswa dapat terlibat langsung dan lebih aktif dalam kegiatan pembelajaran, maka dapat meningkatkan hasil belajar siswa.

Fakor kedua, perpaduan teknik picture and picture dan make a match dalam setting lesson study memberikan kesan yang berbeda pada pembelajaran ini karena terdapat tiga tahap yakni pertama perencanaan, kedua pelaksanaan, dan ketiga refleksi. Teknik picture and picture dan make a match dalam (Lestari \& Afifah, 2018) setting lesson study terlihat lebih baik dibandingkan pembelajaran secara konvensional, dalam pembelajaran tersebut semua siswa bersungguhsungguh dalam menyimak pembelajaran dan sangat antusias dalam mengikuti pembelajaran hal ini terbukti dengan semua siswa menjawab LKS dengan tepat. Selain itu diskusi siswa mulai menunjukkan sikap bertanggung jawab dan menjawab pertanyaan yang berpedoman pada LKS. Informasi dalam pembelajaran yang dapat merangsang pikiran, perasaan, perhatian dan kemauan siswa sehingga dapat mendorong terjadinya proses belajar pada diri siswa.

Temuan penelitian ini didukung dengan hasil penelitian sebelumnya yang dilakukan oleh Gita Septinauli Sidabutar tahun 2018 yang dilihat dari penggunaan lesson study, melalui setting lesson study membuktikan bahwa berpengaruh terhadap hasil belajar. Setting lesson study dilakukan untuk kegiatan perbaikan dalam proses pembelajaran, karena guru dapat meningkatkan kualitas pembelajaran serta keprofesionalan yang dapat meningkatkan kualitas pembelajaran serta memperoleh siswa yang memiliki kualitas unggul (Supranoto, 2016). Dalam Supranoto (2016:21) "Lesson study adalah kegiatan perbaikan guru dalam melakukan proses pembelajaran di kelas". Maka setting lesson study berupa bentuk peningkatan kualitas pembelajaran dan pengembangan keahlian pendidik dalam melakukan proses pembelajaran di kelas, serta menerapkan bermacam teknik, metode/strategi pembelajaran yang tepat dihadapi oleh guru.

Berdasarkan hasil penelitian yang dilakukan serta diperkuat oleh pendapat Mawardi dan Desty (2015:86) menemukan hasil bahwa picture and picure dan make a match yang memiliki kemampuan seimbang dalam meningkatkan hasil belajar, dikarenakan penggunaan teknik picture and picture dan make a match sama-sama menuntut siswa untuk aktif, berpikir kritis, percaya diri dalam mengkomunikasikan hasil kerja melalui penggunaan gambar serta kartu yang berisikan soal/jawaban yang disediakan. Penelitian tersebut diperkuat pula oleh Eko Prihatiningsih tahun 2018 yang menemukan hasil picture and picture dan make a match memiliki kemampuan yang seimbang dalam meningkatkan hasil belajar. 
Berdasarkan pemaparan di atas, dapat disimpulan terdapat perbedaan yang signifikan hasil belajar antara kelompok eksperimen menggunakan teknik picture and picture dan teknik make a match dalam setting lesson study dengan kelompok yng dibelajarkan dengan menggunakan pembelajaran konvensional pada siswa kelas III A SD Negeri 1 Baktiseraga. Selain memberikan dampak bagi siswa, dalam penelitian ini juga berpengaruh terhadap guru dalam penggunaan model pembelajaran kooperatif dengan teknik picture and picture dan teknik make a match dalam setting lesson study dapat dijadikan bahan banding serta masukan berharga dalam meningkatkan kualitas proses dan hasil belajar siswa. Dampak dari pemberian perlakuan yang diberikan tidak hanya bermanfaat bagi siswa dan guru saja, melainkan memiliki dampak bagi kepala sekolah yaitu menambah informasi berharga bagi sekolah yang dipimpinnya untuk mengambil kebijakan yang tepat dalam kaitannya dengan teknik pembelajaran yang efektif dan efisien di sekolah. Sedangkan bagi peneliti lain yaitu dapat dijadikan bahan refrensi untuk melakukan penelitian yang dilaksanakan dalam menerapkan teknik pembelajaran.

Melalui penggunaan media yang lebih inovatif dan menarik dan disesuaikan dengan perkembangan zaman yang berkembang maka akan menambah penggunaan teknik picture and picture dan make a match lebih menarik dengan bantuan teknologi yang semakin berkembang.

\section{Simpulan dan Saran}

Berdasarkan tujuan penelitian, dapat disimpulkan bahwa terdapat pengaruh signifikan pada kelompok eksperimen yang dibelajarkan dibelajarkan melalui model kooperatif dengan teknik picture and picture dan $\mathrm{k}$ make a match melalui setting lesson study dengan kelompok kontrol yang dibelajarkan guru seperti biasa pada hasil belajar siswa III A. Berdasarkani hipotesis yang dilakukan melalui analisis data menggunakan uji-t yang dibantu menggunakan SPSS 25.00 for Windows dan dengan melihat tabel keputusan yang didapat nilai Sig.(2-tailed) di peroleh 0,043 yang artinya nilai signifikansi (2-tailed) $<0,05(0,043<0,05)$ karena nilai sig. (2-tailed) $<0,05$ $(0,043<0,05)$ maka $\mathrm{H}_{0}$ ditolakdan $\mathrm{H}_{1}$ diterima yang artinya ada pengaruh yang signifikan dari pemberian treatment, maka diartikan bahwa: Ada pengaruh signifikan terkait kelompok eksperimen terkait dibelajarkannya melalui bantuan teknik picture and picture dan teknik make a match melalui setting lesson study dengan kelompok kontrol yang dibelajarkan guru seperti biasa pada hasil belajar siswa kelas III A. Saran yang dapat disampaikan berdasarkan penelitian mengarah kepada siswa yang disarankan siswa dapat menjadi aktif, bertanggung jawab dan dapat membentuk interaksi yang positif antara siswa dalam mengikuti proses pembelajaran serta mampu membangun pengetahuannya serta dapat meningkatkan hasil belajar pada pendekatan tematik. Kepada guru disarankan untuk dapat menggunakan strategi pembelajaran yang inovatif dan menyenangkan agar dapat membantu siswa untuk dapat memahami materi dengan baik. Berdasarkan hasil penelitian ini Kepala Sekolah diharapkan dapat menciptakan kondisi yang mampu mendorong para guru untuk mencoba menerapkan teknik-teknik pembelajaran yang sesuai dengan karakteristik kurikulum 2013 untuk meningkatkan kualitas proses pembelajaran di sekolah. Kepada peneliti lain disarankan memperhatikan lagi kendala-kendala yang terjadi terkait penelitian ini sebagai acuan pertimbangan dalam perbaikan, penyempurnaan penelitian yang akan dilaksanakan.

\section{Daftar Pustaka}

Afiyahni, F. D., Huda, C., \& Listyarini, I. (2019). Keefektifan Model Pembelajaran Kooperatif Think Pair and Share Berbantu Media Diorama Terhadap Hasil Belajar Tematik Integratif. Mimbar PGSD, 7, 230-236.

Andriani, D., Sulasmoni, B. S., \& Setyaningtyas, E. W. (2019). Efektivitas Penerapan Model Pembeljaran Koopertif Tipe Picture and Picture dan Example non Example Terhadap Hasil Belajar pada Pembelajaran Tematik Kelas IV SDN Gugus Ki Hajar Dewantara. Jurnal Basicedu, 3(2), 553-338. Retrieved from https://jbasic.org/index.php/basicedu

Anggraeni, Anggita, A., \& Veryliana, P. (2019). Pengaruh Model Pembelajaran Kooperatif Tipe Make A Match Terhadap Motivasi dan Hasil Belajar Matematika. International Journal of Elementary Education, 3(2), 218-225. 
Arnista, S., Saputra, H. J., \& Azizah, M. (2019). Keefektifan Model Pembelajaran Make A Match terhadap Hasil Belajar dan Motivasi Belajar Matematika. Jurnal Mimbar PGSD Undiksha, 7(3), 214-220.

Azhar, D., Suranata, K., \& Dharsana, I. K. (2019). Efektivitas Model Konseling Behavioral Pavlov dengan Teknik Classical Conditioning untuk Meningkatkan Self Achievement. JIBK Undiksha, 10(2), 58-64. https://doi.org/10.24036/XXXXXXXXXX-X

Budiarto, E. (2004). Metodologi Penelitian Kedokteran. Jakarta: Penerbit Buku Kedokteran.

Cahyani, I. G. A. A. N., Tegeh, i M., \& Sudarma, I. K. (2015). Pengaruh Model Pembelajaran Kooperatif Tipe STAD Berbantuan Multimedia Pembelajaran Terhadap Hasil Belajar PKN. EJournal Edutech, 3(1).

Daryanto, \& Rahardjo, M. (2012). Model Pembelajaran Inovatif. Yogyakarta: PENERBIT GAVA MEDIA.

Dharsana, I. K. (2014). Model-model, Teori, Teknik, Skill Bimbingan Konseling (Universita). Singaraja.

Dharsana, I. K. (2018). Bimbingan Anak Berkebutuhan Khusus (ABK). Singaraja: BK FIP Undiksha.

Dharsana, I. K., Suarni, N. K., \& Mahendra, I. G. N. A. (2019). Efektivitas Konseling Behavioral dengan Teknik Modeling Melalui Lesson Study untuk Meningkatkan Self Nurturance. Jurnal Mimbar IImu, 24(2), 167-173. Retrieved from e-issn:2685-9033

Laila, I., Dharsana, I. K., \& Suarni, N. K. (2019). Efektivitas Konseling Behavioral dengan Teknik Modeling untuk Meningkatkan Self Autonomy Melalui Lesson Study. Ilmiah Bimbingan Konseling Undiksha, 10(2), 87-91. https://doi.org/10.24036/XXXXXXXXXX-X

Lestari, R., \& Afifah, N. (2018). Penerapan Lesson Study untuk Meningkatkan Kemampuan Dasar Mengajar Mahasiswa Pendidikan Biologi Universitas Pasir Pengaraian. 37-41.

Margunayasa, G., Arini, W., \& Japa, N. I. G. (2014). Pembelajaran Terpadu. Yogyakarta: Graha IImu.

Mukrimah, S. S. (2014). 53 Metode Belajar dan Pembelajaran (S. S. Mukrimah, ed.). Bandung: Universitas Pendidikan Indonesia.

Murtinugraha, R. E., \& Arthur, R. (2014). Kualitas ButirTes Pilihan Ganda pada Program Keahlian Teknik Gambar Bangunan. FT UNJ, (1), 53-69.

Putra, P. A. D., Sudarma, I. K., \& Tegeh, I. M. (2015). Pengaruh Model Pembelajaran Kooperatif Tipe GI (Group Investigation) Berbantuan Multimedia Interaktif Terhadap Hasil Belajar IPA. EJournal Edutech Universitas Pendidikan Ganesha, 3(1).

Sakdiah, S. (2019). Upaya Meningkatkan Kualitas Proses Pembelajaran dan Penilaian Hasil Belajar Melalui Supervisi Akademik Di Sd Binaan Kota Lhokseumawe Tahun 2019. Serambi PTk, 6(3), 134-142.

Sri, Y. (2018). Efektifitas Model Pembelajaran Base Learning pada Peningkatan Kemampuan Pemecahan Masalah Siswa. Histogram, 2(2), 156-168.

Sukmawati, N. M. I., Dantes, N., \& Dibia, I. K. (2019). Pengaruh Model Pembelajaran Picture and Picture Terhadap Keterampilan Menulis Narasi. E-Journal PGSD, 7, 198-206.

Supranoto, H. (2016). Penerapan Lesson Study dalam Meningkatkan Kompetensi Padagogik Guru SMA Bina Mulya Gadingrejo Tahun Pelajaran 2015/2016. Jurnal Promosi Jurnal Pendidikan Ekonomi UM Metro, 3(2), 21-28.

Tristiantari, N. K. D., \& Sumantri, I. M. (2016). Model Pembelajara Cooperatif Integrated Reading Composition Berpola Lesson Study Meningkatkan Keterampilan Membaca dan Menulis. 
Jurnal Pendidikan Indonesis, 5(2), 206.

Undang-Undang Republik Indonesia No. 22 Tahun 2006. Standar Isi untuk Satuan Pendidikan Dasar dan Menengah. Jakarta. 